\title{
EPILOG BURZY ZBIGNIEWA HERBERTA (NA MARGINESIE KERYGMATYCZNEJ INTERPRETACJI PRZESLANIA PANA COGITO)
}

W artykule Kerygmatyczna interpretacja «Przestania Pana Cogito» Marian Maciejewski poprzedził rozważania dotyczące „,najsłynniejszego" wiersza Herberta następującym fragmentem:

Człowiek jest niewolnikiem Pana Śmierci ze względu na strach, jaki ma przed śmiercią - która ileż ma imion $[\ldots]^{1}$.

W szkicu Norwida «Fatum ukrzyżowane» zaś pisał o „bolesnym odczuciu niszczącego działania czasu w historii jednostkowej, czasu zmierzającego do śmierci”’2. W tej perspektywie: uciekającego czasu, świadomości kresu i domknięcia życia, „obłaskawiania nieszczęść” choroby, starości i cierpienia chcę przyjrzeć się ostatniemu tomowi Zbigniewa Herberta. Epilog burzy ukazał się w roku śmierci poety - 1998.

W przywołanym tekście Maciejewskiego znajduje się fragment, który sytuuje się nieco na marginesie rozważań dotyczących Przesłania Pana Cogito. Chodzi o interpretację wiersza Przepaść Pana Cogi$t o^{3}$. Badacz eksponuje w nim topos „strachu przed śmiercią”, który $\mathrm{w}$ poetyckiej metaforyce odsłania się $\mathrm{w}$ obrazie przepaści. Jest ona „uciążliwa jak egzema / przywiązana jak pies”; to stała towarzyszka Pana Cogito: ,idzie za nim jak cień / przystaje pod piekarnią / w parku

\footnotetext{
Marian Maciejewski, Kerygmatyczna interpretacja «Przesłania Pana Cogito», „Polonistyka” 1992, nr 7/8, s. 404.

2 Marian Maciejewski, Norwida «Fatum ukrzyżowane», w: tegoż, «ażeby ciało powróciło w słowo». Próba kerygmatycznej interpretacji literatury, Lublin 1991, s. 135.

3 Interpretację tego wiersza przedstawia także Małgorzata Łukaszuk-Piekara w artykule: «Przepaść Pana Cogito»-między antypodami życia, „Roczniki Humanistyczne” 1999, z. 1, s. 73-93. Tu zwrócenie uwagi na odmienne wersje wiersza.
} 
przez ramię Pana Cogito / czyta z nim gazetę" (Przepaść Pana Cogito, PC, s. 19) ${ }^{4}$. Maciejewski podkreśla:

Przepaść utraciła swoje imię, czyli właściwą istotę głębi [...]. Mocą metafory poeta ,przestawił” wymiar przepaści z ,głębinowego" na przestrzenny, horyzontalny, płytki, ale długi jak życie.

Przepaść odczytana metaforycznie jest „wziernikiem w śmierć ontyczną współczesnego człowieka spowodowaną przez śmierć”5. W poezji Herberta śmierć jawi się jako unicestwienie nie tylko ciała, ale także wartości i humanistycznej wizji człowieka. Warte podkreślenia w tej interpretacji jest szczególne zwrócenie przez Maciejewskiego uwagi na poziomy wymiar tytułowej przestrzeni - jej rozciągnięcie, które odsłania swoją obecność w zasadzie w każdym momencie życia Pana Cogito. To wyraźny głos, który nie pozwala zapomnieć o tym, że przemijamy.

W wierszu Pan Cogito - zapiski z martwego domu Herbert pisał o „wołaniu przepaści” (ROM, s. 97). Wobec tego głosu zachowanie Pana Cogito przypomina „egzorcyzmowanie czasu”, o którym pisał Maciejewski w Norwida "Fatum ukrzyżowanym». Jednym ze złudnych sposobów ,zapomnienia” o strachu przed Panem Śmierci było skupienie się na tym, co obecne - „napawanie się chwilą, ową Byronowską «kroplą wieczności»”. Bohater Herberta „wychodzi na spacer”, ,przystaje przed piekarnią”, ,czyta gazetę”- podejmuje działania najprostsze, zwyczajne. Ich powtarzalność nie niweluje bliskiej obecności przepaści. Bycie obok wywołuje specyficzną relację - bo Pan Cogito rozważa naturę i status swojej towarzyszki. Co więcej - dba o jej trwanie, zostawiając ją za progiem domu, przykrywając ją ,kawałkiem starej materii”. Przepaść jest bowiem ,na miarę Pana Cogito". Ta troska jest być może zgodą na obecność śmierci, wyrazem chęci zbliżenia się i zrozumienia tego, co graniczne, bolesne i nieuchronne. Specyficzna ,przyjaciółka” Pana Cogito jest potraktowana tak samo,

\footnotetext{
$4 \quad$ Wszystkie wiersze Herberta cytuję z podaniem w nawiasie tytułu tomu (skrótem), z którego pochodzą, i numeru strony wg: Raport z oblężonego Miasta $i$ inne wiersze (ROM), Wrocław 1993; Pan Cogito (PC), Wrocław 1997; Epilog burzy (EB), Wrocław 1998.

5 Marian Maciejewski, Kerygmatyczna interpretacja «Przesłania Pana Cogito», dz. cyt., s. 405.
} 
jak cierpienie: zostaje dostrzeżona i przyjęta (zob. Pan Cogito rozmyśla o cierpieniu, PC, s. 17-18).

Przepaść to także obraz świadomości przemijania, „przyklejony” do pojedynczej biografii. W przywoływanym przeze mnie artykule Maciejewski wyróżnia dwa rodzaje świadomości: zbiorową oraz indywidulaną. Ta pierwsza, obecna w Przestaniu Pana Cogito, jest ratunkiem dla zagrożonego totalitaryzmami człowieczeństwa. Świadomość zbiorowa, archetypiczna przejawia się w solidarności z zamierzchłymi przodkami („Gilgameszem, Hektorem, Rolandem”). Ocalenie przychodzi dzięki wysiłkowi człowieka - pisze Maciejewski, podkreślając obecność „laickiego heroizmu” w tekście Herberta ${ }^{6}$. Świadomość indywidulana ma wymiar najbardziej osobisty, w utworze Pan Cogito powrót czytamy, że tytułowy bohater ,,przestał wierzyć w postęp, obchodzi go własna rana" (ROM, s. 23). Przepaść przywołuje ranę, cierpienie - to, co najbardziej własne, ,szyte na miarę”.

W obliczu tej rany - warto zapytać, jak kształtuje się świadomość bohatera Epilogu burzy. Jeśli w Przepaści Pana Cogito miała ona wymiar horyzontalny, płytki, warto postawić pytania o sposoby funkcjonowania przestrzeni, a zatem i świadomości cierpienia i śmierci, $w$ wierszach ostatnich poety. Czy wymiar horyzontalny wciąż jest widoczny? W przywoływanym tekście z tomu Pan Cogito tytułowa przepaść nie przekraczała progu domu, istniały miejsca, w których przez chwilę nie był słyszalny jej głos. Jakie są przestrzenie ,bezpieczne” w Epilogu burzy? Czy Herbert idzie ścieżką „uwiecznień” i „,egzorcyzmowania czasu”, którą Maciejewski wyznaczył romantykom? Wreszcie: czy przepaść odzyskuje swoje imię, to znaczy głębię? Czy wyrośnie, dojrzeje i będzie poważna - parafrazując słowa z wiersza poety? Czy bohater Herberta w sytuacji granicznej zdobędzie wiedzę o tym, ,jaką [przepaść] pije wodę” i ,jakim karmić ją ziarnem" (Przepaść Pana Cogito, PC, s. 20)?

Już sam tytuł ostatniego tomu Herberta wyznacza perspektywę domknięcia, kresu, dopowiedzenia historii życia, losu, doświadcze-

\footnotetext{
Tamże.
} 
nia ${ }^{7}$. By objaśnić sens tego, co było, potrzebna jest inna perspektywa spojrzenia - niejako z zewnątrz. Stąd tak wiele w tym tomie obrazów ukazujących czas i wydarzenia w perspektywie zamkniętej, kolistej, przebiegającej „od - do”. Wszechświat opowiadany jest „od piątku / do niedzieli” (Babcia, EB, s. 5); „,skrzypi oś świata” i mijają „,kolorowe obręcze czasu” (Dałem słowo, EB, s. 16); rzeczywistość „obraca się wolno w żyłach”, ,wszystko się powtarza” i wszystko już było (Starość, EB, s. 68); życie przerwane śmiercią jest ,jak krótka podróż pierścionka po gładkim stole / który toczy się kołuje / wreszcie staje jak martwy / skarabeusz” (Kant. Ostanie dni, EB, s. 22); ,wssystko już zamknięte" - wyznaje bohater wiersza Pora (EB, s. 67) ${ }^{8}$.

Świadomość odchodzenia, doświadczenie choroby i starości wywołuje w Panu Cogito chęć „,egzorcyzmowania czasu”, o którym Maciejewski pisał, że w sytuacji indywidualnej biografii jest próbą „,obłaskawienia nieszczęścia"9. Czas jest bowiem źródłem permanentnego cierpienia, bo obdarza świadomością przemijania. Badacz wymienia różne próby „uwiecznień”, które mogą dawać pocieszenie i niwelować (tylko cząstkowo!) bolesne odczucie niszczącego działania czasu. Pierwszą z nich jest utrwalanie w kulturze, zwłaszcza w kreacyjnym słowie poetyckim, następnie skupienie się na chwili, która jawi się jako „kropla wieczności”. Ważną formą „obłaskawiania nieszczęścia” jest wędrówka w poszukiwaniu utraconego czasu, do Arkadii dzieciństwa, a także projekcje w przyszłość, jawiącą się jako alegoria wieczności ${ }^{10}$.

W otwierającym cały tom utworze Babcia Herbert przywołuje motyw podróży do krainy dzieciństwa. We wspomnieniu postać „Marii z Bałabanów" jawi się jako ta, która ukazuje i objaśnia świat ${ }^{11}$. Powrót

\footnotetext{
7 O takiej interpretacji tytułu pisze Anna Legeżyńska w artykule Gest pożegnania, w: tejże, Dom i poetycka bezdomność w liryce wspótczesnej, Warszawa 1990, s. 90, oraz Jacek Brzozowski w artykule «Epilog Burzy», w: Twórczość Zbigniewa Herberta, pod red. Marzeny Woźniak-Łabieniec, Jerzego Wiśniewskiego, Kraków 2001, s. 271-298.

8 Zob. Andrzej Tyszczyk, «Kant. Ostatnie dni». Jeden czy dwa teksty?, „Roczniki Humanistyczne" 2000, t. 47, z. 1, s. 27-38.

9 Zob. Marian Maciejewski, Norwida «Fatum ukrzyżowane», dz. cyt., s. 135.

10 Tamże.

11 O swojej babci, Marii z Bałabanów, mówił Herbert w wywiadzie udzielonym ks. Januszowi
} 
na jej czułe kolana, wsłuchiwanie się w opowieści nie jest jednak sposobem na „obłaskawienie nieszczęścia”. To spotkanie jest początkiem dorastania bohatera i zdobywania przez niego prawdy o świecie. Bezpieczny azyl, jakim były kolana „Marii Doświadczonej”, został na zawsze opuszczony. „Kilka lat złudzeń” przeminęło i w niedotkniętą cierpieniem rzeczywistość wsącza się okrutna historia: „masakra Armenii” i „masakra Turków” (Babcia, EB, s. 6). W wierszu Herberta powrót do Arkadii nie jest równoznaczny z ucieczką od Nieszczęścia. Pozwala jedynie w domkniętej perspektywie czasu (od dzieciństwa, od źródła) dostrzec proces dojrzewania do „nagiego" (tego słowa używa Maciejewski, pisząc o postawie podmiotu z wiersza Fatum Norwida), bezpośredniego spotkania z cierpieniem i śmiercią. Podmiot wyznaje: ,[...] doczekam / i sam poznam / bez słów zaklęć i płaczu / szorstką / powierzchnię / i dno / słowa" (Babcia, EB, s. 6).

Powroty do dzieciństwa, zwłaszcza domu i miasta rodzinnego, przywołane zostały także w dalszych utworach tego tomu: $W$ mieście oraz Wysoki Zamek. Tu także jednak nie mamy do czynienia z ucieczką do szczęśliwej krainy. W wierszu pt. W mieście powrót nie jest możliwy - podmiot dwukrotnie wyznaje: ,w mieście kresowym do którego nie wrócę” i „w moim mieście dalekim do którego nie wrócę” i zaraz dodaje: „W moim mieście którego nie ma na żadnej mapie / świata”"12. To miasto strzeżone przez pamięć, niedostępne, w którym ,jest taki chleb co żywić może / całe życie”, jest też „,iężka i pożywna woda” (EB, s. 52). To pokarmy, którymi karmi się pamięć - woda umożliwia powrót, chleb - przetrwanie. Czy nimi mogłaby nakarmić się przepaść Pana Cogito? Tak, jeśli założymy, że wraz z upływem czasu odkładają się i przyrastają kolejne doświadczenia, zwłaszcza te, które przynoszą

\footnotetext{
St. Pasierbowi, zob. Janusz St. Pasierb, Dramat, który nadaje nam godność. Rozmowa ze Zbigniewem Herbertem, w: tegoż, Zgubiona drachma. Dialogi z pisarzami, Warszawa 2006, s. 49-66.

12 Por. Czesław Miłosz, W mojej Ojczyźnie, w: tegoż, Poezje, Warszawa 1982, s. 38. Datowany na 1937 rok liryk Miłosza został opublikowany w tomie Ocalenie (1945). Marian Maciejewski przywołał ten utwór w szkicu Literatura w świetle kerygmatu jako przykład tekstu, który wykorzystując motyw wspomnienia i powrotu do dzieciństwa, ,zatrzymuje czas, wprowadzając wymiar złudnie osiągniętej wieczności” (zob. M. Maciejewski, «ażeby ciało powróciło w słowo»..., dz. cyt., s. 15).
} 
cierpienie. Życie nie jest wolne od tych wydarzeń, w wierszu Brewiarz [Panie wiem że dni moje sa policzone...] Herbert pisał:

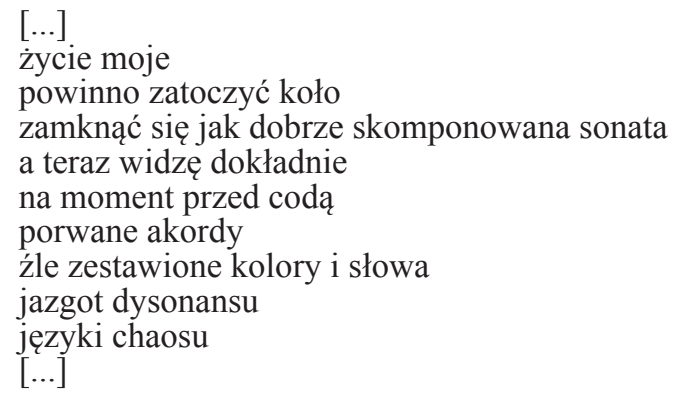

Bohater ostatnich wierszy Herberta, nie tylko ma świadomość ciągłego dorastania, dojrzewania, ale także jest w stanie zobaczyć swój los jako proces, który prowadzi - właśnie do tego ostatecznego momentu, do pożegnania, odejścia. W Wysokim Zamku Herbert opisuje ten moment jeszcze za pomocą metafory:

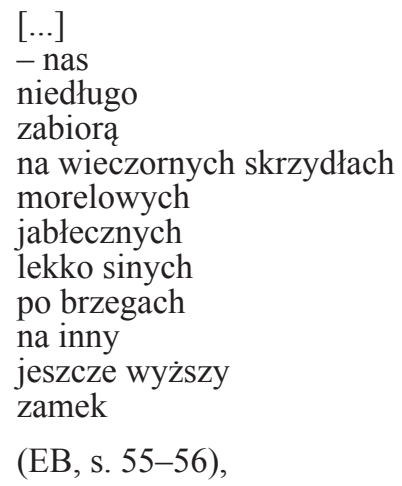

ale już w wierszu o znamiennym tytule Koniec mówi wprost, bez wyszukanego języka, potoczną składnią: 
A teraz to nie będzie mnie na żadnym zdjęciu zbiorowym (dumny dowód mojej śmierci we wszystkich literackich tygodnikach świata) kiedy ktoś powie patrzcie widzicie - to Zbyszek - wskazując palcem na mężczyznę który szamoce się z walizką - ale to nie ja to ktoś inny nawet nie jest $z$ tej branży nie ma mnie i nie ma zupełna pustka nawet gdybym skupił wolę w jedno ognisko nie potrafiłbym na moment nawet w błysku magnezji zaistnieć więc nie ma szlus

$[\ldots]$

(EB, s. 24)

W tej bezpośredniości słowa, które nie chowa się za zasłoną wyszukanej stylistyki, Maciejewski widział przejaw kerygmatu pozytywnego w literaturze. Zajęcie pozycji otwartej, przyjęcie cierpienia, mierzenie się ze świadomością umierania, przypomina odważną postawę bohatera wiersza Norwida Fatum, który „odpowiedział” na fakt Nieszczęścia ${ }^{13}$.

Świadomość przemijania dotyczy także Pana Cogito, który krząta się i przygotowuje do dalekiej podróży, jest „W stanie gotowości” z duszą umieszczoną na ramieniu, która „być może opuści / ciało Pana Cogito / we śnie" (Pan Cogito. Aktualna pozycja duszy, EB, s. 31). Dla bohatera Herberta to czas pożegnań. Pan Cogito wspomina swoje dzieciństwo i młodość we Lwowie (Pan Cogito. Lekcja kaligrafii, EB, s. 63-65), oglądane filmy i przeczytane lektury. W dwóch ostatnich wierszach poświęconych tej postaci widoczna jest już głęboka świadomość śmierci, ale także istnienia innego wymiaru życia. W Zaświatach Pana Cogito Herbert napisze: „ten świat / to właściwie tamten świat”, śmierć jawi się jako podróż, do której nigdy ostatecznie nie będziemy przygotowani (EB, s. 71). W Urwaniu głowy czytamy:

$[\ldots]$

więc pewnego dnia

lub nocy

13 Zob. Marian Maciejewski, Norwida «Fatum ukrzyżowane», dz. cyt., s. 139. 


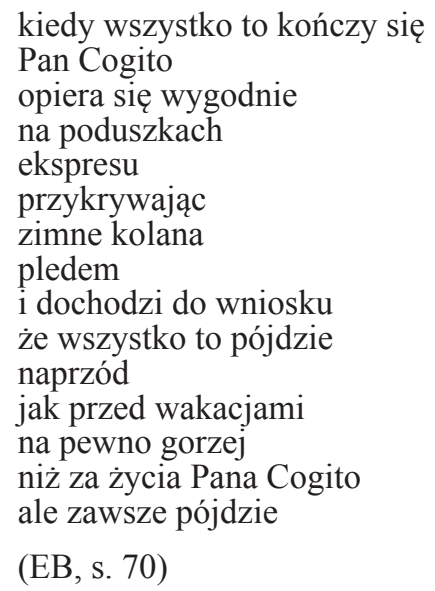

Przepaść Pana Cogito miała wymiar horyzontalny, była płytka, straciła - jak pisał Maciejewski - swoją podstawową właściwość: głębię. W Epilogu burzy ruch ku śmierci (rozumiany jako zmiana, a nie tylko przemieszczenie się), ostatnia podróż odbywa się także w tym horyzontalnym wymiarze. Ale to nie jedyny jej wymiar. W ostatnim tomie Herberta obok wymiaru poziomego istotną rolę odgrywa to, co zanurza się, pogłębia, tonie. Jest tak, jakby dotychczasowa „przepaść” dojrzała i wreszcie odkryła swoją głębię. Dostrzeżenie jej możliwe jest tylko wówczas, gdy ustanie wędrówka, nastąpi zatrzymanie.

W lirykach ostatnich Adama Mickiewicza Maciejewski dostrzegał próby zatrzymania czasu - poprzez ucieczkę w Arkadię dzieciństwa lub przez podkreślenie wagi przeżywanej chwili. Doświadczanie wieczności wypowiedziane zostało zatem poprzez powrót do tego, co zachowane w pamięci, ocalone przed upływem czasu oraz poprzez dowartościowanie momentu teraźniejszości ${ }^{14}$. W Epilogu burzy przeczucie wieczności odsłania się w momencie skupienia podmiotu na cierpieniu, zwłaszcza doznaniach jego umierającego ciała. Świadomość

\footnotetext{
14 Zob. Marian Maciejewski, Przestanie z «drugiego brzegu». Mickiewicza liryka lat ostatnich, w: tegoż, «ażeby ciało powróciło w słowo»..., dz. cyt., s. 107.
} 
nieuchronności śmierci potwierdza ból choroby i samotność, a jednocześnie umożliwia spojrzenie na życie w perspektywie wieczności.

Epilog burzy opiera się na dwóch symbolicznych motywach: życie rozumiane jest jako ruch, przemieszczanie się, wieczność natomiast jako przestrzeń docelowa i głębia. Te dwa wymiary zbliżają się do siebie u kresu ludzkiej wędrówki. Pan Cogito, ale i liryczny bohater tego tomu, przebywa ostatni etap drogi, mając jednocześnie świadomość tego, że już za moment trzeba się będzie zatrzymać. Na razie pozostaje niejako na granicy, kiedy „dusza staje się boleśnie wątłą pajęczyną" (Strefa liryczna, EB, s. 45). Oddanie stanu „,na chwilę przed”, ,pomiędzy" doskonale wyraża utwór Czas; Herbert pisze:

$[\ldots]$

oto żyję w różnych czasach, nieruchomy, a wyposażony

we wszystkie ruchy, bowiem żyję w przestrzeni i należę do niej

i wszystko co jest przestrzenią użycza mi jej przejmującej, przemijającej

formy;

oto żyję w różnych czasach, nie istniejący boleśnie nieruchomy

i boleśnie ruchliwy i nie wiem zaiste, co mi jest dane, a co odjęte

na zawsze

(EB, s. 62)

Jednak to unieruchomienie już za chwilę umożliwi odbycie ruchu w głąb, to znaczy ku wieczności. Jej podstawowym obrazem jest woda.

Marian Maciejewski, pisząc o Lirykach lozańskich Mickiewicza, podkreślał, że rysuje się w nich przestrzenna głębia, potrzebna do zobrazowania czasu wiecznego. I dodawał:

„głębia” i „płytkość" ewokują poza dosłownymi sensami przestrzennymi, również znaczenia moralne. [...] Przedmiotem, który poprzez określoną lokalizację przestrzenną, ewokuje znaczenia symboliczne, jest woda. Gaston Bachelard, najwybitniejszy znawcza jej ,,duszy”, kojarzy ją z ,dialektyką trwania i przemijania czasu, sądząc, że tylko w bardzo powierzchownym odczuciu woda płynie, naprawdę zaś - trwa". Trwanie należy więc do ,istoty” wody. Z kolei kwalifikacja aksjologiczna - wyciszenie, głębia, czystość - będąc wprost proporcjonalną do intensyfikacji rozmiaru i właściwości, funduje wodzie istnienie w przestrzeni mitycznej, o której 
można by z kolei powiedzieć, że jest odwrotnie proporcjonalna do czasu ${ }^{15}$.

W Epilogu burzy Herbert przywołuje obraz wody, kiedy mówi o początku i o wieczności. W wierszu Brewiarz [Panie wiem że dni moje sa policzone...] bohater zadaje sobie pytanie:

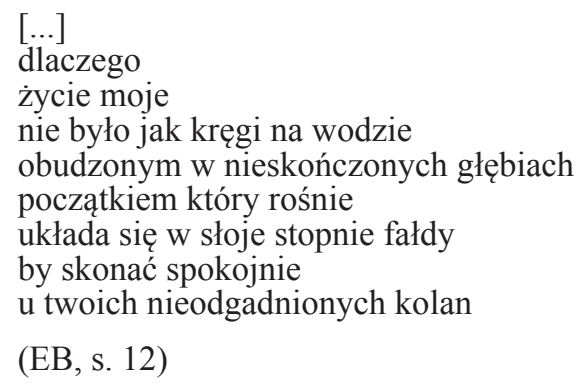

Stopnie i fałdy, rośnięcie - ukazują życie jako wzrastanie, wznoszenie się, przeciwne do linearnego i płytkiego wymiaru, jakim charakteryzowała się przepaść Pana Cogito. Świadomość konieczności oderwania się, wzbicia pogłębia się w momencie oceny życia już u jego kresu. „Porwanym akordom” istnienia wychodzi naprzeciw pełnia: „kręgi na wodzie”; „bolesnemu ruchowi” - trwanie „owada w bursztynie” (Czas, EB, s. 62); , ,czołu w bruzdach” i ,sinemu światłu poranka” odpowiada dotyk, który „prowadzi z góry / ręka Mistrza” (Tomasz, EB, s. 51).

Ruch i trwanie, powierzchnia i głębia odzywają się niemal w każdym wierszu tego tomu. Bohater poznaje ,szorstką / powierzchnię / i dno / słowa” (Babcia, EB, s. 6), „tonie” „od niepamiętnych czasów” w „kramie życia” (Brewiarz [Panie, dzięki Ci składam za cały ten kram $\dot{z y c i a \ldots . .], ~ E B, ~ s . ~ 7) . ~ W ~ m o d l i t w i e ~ p r o s i ~ o ~ „ b a s ~ c z y s t y c h ~ g ł e ̨ b i n ” ~ w y d o-~}$ byty z ,fałdów morza”. Miejscem czułości jest „wnętrze dłoni” i „dno oka" (Czułość, EB, s. 74).

\footnotetext{
15 Marian Maciejewski, Mickiewiczowskie «czucia wieczności», w: Mickiewicz. Sympozjum w Katolickim Uniwersytecie Lubelskim, pod red. Anny Dobakówny, Czesława Zgorzelskiego i in., Lublin 1979, s. 341.
} 
Przestrzeń Epilogu burzy ukazuje, podobnie jak Liryki lozańskie Mickiewicza, dwie symboliczne płaszczyzny: drogę i zatrzymanie, powierzchnię i głębię, domykanie i otwarcie na nowe. O ich pojednanie umierający prosi następująco:

Panie,

pomóż nam wymyślić owoc

czysty obraz słodyczy

a także spotkanie obojga płaszczyzn

zmierzchu i zaranka

$[\ldots]$

(Brewiarz [Panie pomóż nam wymyślić owoc...], EB, s. 10)

Ma bowiem świadomość, że zabiera „na brzeg niedaleki” wszystko: „,krosna wierności”, „czółno i wątek osnowy i całun” (Tkanina, EB, s. 76) ${ }^{16}$.

W opracowaniu Mariana Maciejewskiego przepaść Pana Cogito była swoistym toposem ,strachu przed śmiercią". Epilog burzy zanurza się w śmierci, pozwala przepaści odzyskać jej głębię. Dzieje się tak, ponieważ bohater tego tomu ma świadomość, że głębia nie jest pustką. Na jej dnie znajdują się przecież ,nieodgadnione” kolana Boga (we wspomnieniach powracał do bezpiecznych kolan babci - teraz w perspektywie wieczności kolana są miejscem najbardziej bezpiecznym, dobrym). Przepaść nie jest też czeluścią bez dna, bo po drugiej stronie jest ,brzeg niedaleki”. O ile podmiot z wiersza Przestanie Pana Cogito przyjmował postawę „samozbawienia” (M. Maciejewski), o tyle w ostatnim tomie Herberta bohater dostrzega i uznaje Tego (cyk1 Brewiarz), który jest poza nim samym i który silniejszy jest od śmierci.

\footnotetext{
16 O zamykającym Epilog Burzy wierszu pisali m.in. Paweł Panas, Cieniem nakryci po oczy. Śmierć i jej postacie w twórczości Zbigniewa Herberta, w: Czułość dla Minotaura. Metafizyka i mitość konkretu w twórczości Zbigniewa Herberta, pod red. Józefa Marii Ruszara, Lublin 2005; Barbara Stelmaszczyk, Epilog na odejście, w: Twórczość Zbigniewa Herberta, dz. cyt.; Dagmara Zawistowska-Toczek, Stary poeta. Ars moriendi w późnej twórczości Zbigniewa Herberta, Lublin 2008.
} 


\section{Summary}

Zbigniew Herbert's Epilogue to a Storm (on the margins of a kerygmatic interpretation of Last Message from Mr. Cogito)

Zbigniew Herbert's Epilogue to a Storm, last volume by the poet, sets the perspective of a finish and a finale. Death and different ways of getting closer to what is beyond death is one of the leading subjects of the volume. Marian Maciejewski created main interpretative tropes in Herbert's poetry; they are related to the topos of 'fear of death' and the 'autosalvation' stance that defines the protagonist of Last Message from Mr. Cogito. One can see in Epilogue to a Storm a number of ways of 'exorcising time' put forward by the researcher: instances of going back to childhood, memories of hometown, registration of 'the moment'. Reflections on death take place on two levels: horizontal and vertical. The former symbolises life understood as journey, and its basic image is water. The latter is linked to halt and profoundness, which refer to death and eternity (the Brewiarz cycle). 